\title{
The Role of Fluid Recovery in Consumer Protection Litigation: Kraus v. Trinity Management Services
}

\author{
Stan Karas†
}

\section{TABLE OF CONTENTS}

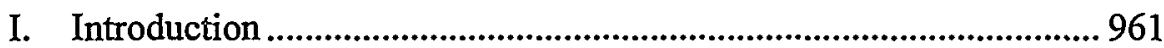

II. Consumer Protection and Fluid Recovery in California ................... 964

A. Consumer Protection Through Class Action Litigation.............. 964

B. Consumer Protection Through the Unfair Competition Law...... 966

C. The Concept of Fluid Recovery ................................................970

D. Fluid Recovery Case Law in California.................................... 97I

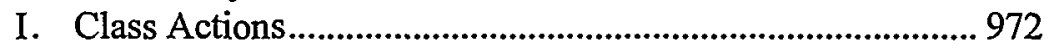

2. Unfair Competition Law ............................................... 974

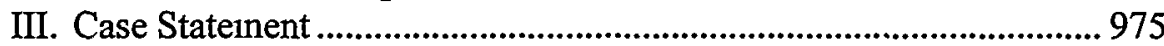

A. Trial Court and Appellate Decisions....................................... 975

B. California Supreme Court Decision.........................................996

IV. The Need for a Legislative Rejoinder to Kraus............................... 978

A. The Problems Created by Kraus ............................................... 978

I. Channeling of UCL-type Claims to Class Action Litigation 979

2. Imposition of an Inefficient Restitution Burden on Defendants...................................................................... 98 I

3. Restriction of Courts' Equitable Powers Under the UCL .... 984

B. The Merits of Fluid Recovery................................................986

1. Furtherance of the UCL's Goals Even Where Restitution

Is Impossible or Impractical ..................................................986

a. Fluid Recovery Is Consistent with the Broad Goals

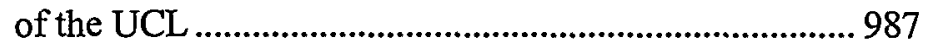

b. Fluid Recovery Is Consistent with the Modern Trend of Pragmatism in Mass Litigation.

Copyright $@ 2002$ California Law Review, Inc. California Law Review, Inc. (CLR) is a California nonprofit corporation. CLR and the authors are solely responsible for the content of their publications.

$\dagger \quad$ J.D. Candidate, School of Law, University of California, Berkeley (Boalt Hall), 2002; A.B., Stanford University, 1999. I would like to thank Eve Coddon, Bob Infelise and William L. Stern for their help on this project. Sarah Shaw and Michael Maher provided excellent editorial assistance. For my parents and friends. 
2. Greater Consistency with Legislative Intent Where the Costs of Notification Exceed the Benefits 991

3. Improved Quality of Consumer Protection Through Grants to Consumer Groups .............................................. 992 Conclusion 


\title{
The Role of Fluid Recovery in Consumer Protection Litigation: Kraus v. Trinity Management Services
}

\author{
Stan Karas
}

In mass litigation it is often impossible or impracticable to compensate all direct victims. In such cases courts often employ "fluid recovery" to put the damage funds to the next best use, such as awarding funds to consumer interest organizations or rolling back the price of the defendants' product. In Kraus v. Trinity Management Services, the California Supreme Court held that fluid recovery is not available in representative actions brought under the state's expansive Unfair Competition Law (UCL). This Casenote analyzes the decision in the context of California's consumer protection jurisprudence, and concludes that although the UCL must be reined in, the courts should be able to employ fluid recovery in consumer protection suits under the statute. Absent legislative intervention, Kraus will lead to improper channeling of UCL suits into class actions, impose an impractical notification burden on defendants, and restrict the courts' historically broad equitable powers under the statute. The Casenote concludes that permitting fluid recovery is in line with the legislative intent of the statute and the trend towards pragmatism in mass litigation.

\section{INTRODUCTION}

The law of remedies focuses on restoring equities and making restitution. ${ }^{1}$ Yet, in the context of mass litigation, identifying and compensating every class member is difficult and often impossible. ${ }^{2}$ In such cases, many courts, including those in California, have employed "fluid recovery" to distribute unclaimed funds or sometimes even the entire fund. ${ }^{3}$ Fluid recovery, often called cy pres distribution, is a means of putting unclaimed

1. See, e.g., Thomas D. Rowe, Jr., The Legal Theory of Attorney Fee Shifting: A Critical Overview, 1982 DuKE L.J. 651, 657 (explaining that making the plaintiff whole underlies much of the law of remedies).

2. See, e.g, Kerry Barnett, Note, Equitable Trusts: An Effective Remedy in Consumer Class Actions, 96 YALE L.J. 1591, 1594 (1987).

3. See infra Parts II.C-D. 
class funds to their "next best use." This next best use usually takes the form of a consumer trust fund or an across-the-board price reduction for a defendant's product until the ill-gotten gains are disgorged. ${ }^{5}$ However, these methods inherently leave some direct victims uncompensated. This Casenote focuses on Kraus v. Trinity Management Services, Inc., ${ }^{6}$ a recent California Supreme Court decision barring fluid recovery in actions brought under the state's Unfair Competition Law ("UCL").

The UCL is California's statutory vehicle for fighting consumer fraud, antitrust violations, and other business practices that harm consumers. The statute's intent is to address the general societal harm that results when business enterprises act illegally or unethically. ${ }^{8}$ The UCL is perhaps the most expansive consumer protection law in the nation. ${ }^{9}$ Although representative actions under the UCL are not class actions, they provide plaintiffs with many of the benefits of class actions without imposing some of the burdensome legal requirements of that device, such as those related to standing, notice, and class certification. ${ }^{10}$ Because the UCL offers the possibility of broad relief without the procedural hurdles of class action litigation, California's plaintiff's lawyers have been extraordinarily active in pursuing unfair competition lawsuits. ${ }^{11}$ However, to the dismay of the state's businesses, ${ }^{12}$ plaintiffs often have sued over rather innocuous

4. Natalie A. DeJarlais, Note, The Consumer Trust Fund: A Cy Pres Solution to Undistributed Funds in Consumer Class Actions, 38 HAsTings L.J. 729, 730 (1987).

5. See id. at 753-55, 759-65.

6. 999 P.2d 718 (Cal. 2000).

7. CAL. Bus. \& Prof. Code $\$ \$ 17200-17209$ (West 2000).

8. See People ex rel. Mosk v. Natl. Research Co., 20 Cal. Rptr. 516, 520-21 (Dist. Ct. App. 1962).

9. A 1996 report to the California Law Review Commission observed: "None of the 16 other state jurisdictions with their own versions of California's Unfair Competition Act give private attorney general status to any person without qualification." Unfair Competition Litigation, 26 Cal. L. Revision Comm'n Rep. 207 (1996).

10. See infra Parts Il.A-B.

11. Catherine L. Rivard, Federal Court Standing in Unfair Competition Law Litigation, 24 L.A. LAw. 16 (2001) ("Perhaps the biggest wave in the ocean of litigation that has swept California in recent years involves claims brought under Business and Professions Code Section 17200, the state's Unfair Competition Law.").

12. See James Anderson, Complaining More Efficiently, S.F. DAlLY J., Sept. 16, 1999, at 9 (noting that for years "state business groups have pushed unsuccessfully for legislation to make it more difficult for plaintiffs to pursue unfair business practice claims"); see also Gail Lees, Where's the Relief, THE RECORDER, June 21, 2000. Lees explains:

From the defendant's perspective, the representative action has all of the negative aspects of a class action-large numbers of people suing at once, represented by an attorney they haven't met who may be motivated largely by the prospect of significant attorneys fees. And they have none of the positive aspects-no post-certification bar on repetitive claims to protect defendants and no inquiry into adequacy of counsel, absence of conflict and predominance of common issues that make claims suitable for group determination.

Together with the UCL's creation of a right of action for violation of other statutes where the legislature declined to provide for one, and the UCL's authorization of deception claims where no one actually has been deceived, it is no wonder that Forbes magazine in 1998 called the UCL a "lawyer's playground." 
practices. ${ }^{13}$ Another problem for businesses is that private settlement of a UCL lawsuit provides no res judicata protection. ${ }^{14}$

Disgorgement of ill-gotten gain is a central feature of the UCL. Fluid recovery is one method of distributing unclaimed disgorged funds. The California Supreme Court traditionally has recognized the propriety of fluid recovery in class actions, and several state appellate courts have done so $\mathrm{m}$ the context of UCL actions. ${ }^{15}$ Generally, California courts have allowed fluid recovery where individual recoveries for all class members are impossible or impractical, such as where a large number of consumers have suffered a small monetary loss. ${ }^{16}$ In the summer of 2000, however, the California Supreme Court held in Kraus v. Trinity Management Services that courts do not have authority to order fluid recovery im a representative UCL action. ${ }^{17}$ Thus, under the UCL, a court may provide monetary relief only to the actual victims of the illegal practice.

This Casenote argues that the Kraus decision imcorrectly emphasized restitution to direct victims over the broader goals of consumer protection embodied by the UCL. Although strong arguments exist for reformmg the UCL, the abolition of fluid recovery in Kraus serves the interests of neither the state's businesses nor its consumers. Indeed, fluid recovery often is a pragmatic and efficient way of restoring equities and serving the goals of consumer protection.

Part II of this Casenote discusses the history of consumer protection in California and explaims the concept of fluid recovery. Part III presents a factual and legal summary of the Kraus case. Part IV considers the immediate implications of Kraus for consumer protection litigation under the UCL. It suggests that the decision will channel UCL litigation into class actions, place mappropriate burdens on defendants, and lead to an unfortunate limitation of trial courts' equitable powers under the statute. Part IV then argues that the legislature should respond to Kraus by amending the UCL expressly to permit fluid recovery.

Id.

13. For example, Tonka Corporation and Toys ' $R$ Us were sued because their advertisements for the "Easy-Bake" oven misstated the cooking time, and the maker of Pokemon cards was sued because the cards allegedly promoted underage gambling. Joshua D. Taylor, Note, Why The Increasing Role of Public Policy in California's Unfair Competition Law Is a Slippery Step in the Wrong Direction, 52 Hastings L.J. 1131, 1132 (2001).

14. See Lees, supra note 12.

15. See infra Parts II.A-B.

16. Id.

17. 999 P.2d 718, 721 (Cal. 2000). 


\section{Consumer Protection and Fluid Recovery in California}

California has a long and illustrious history of consumer protection litigation. One cannot appreciate the impact and the importance of Kraus without understanding its place within that history. This Part begins with a discussion of class action litigation, the first legal device for consumer protection in California. Although procedurally quite different from UCL actions, class actions are relevant to an examination of Kraus because the UCL was not employed widely until the 1970 s, decades after landmark class action decisions laid the foundation for consumer protection through mass litigation in California. ${ }^{18}$ In addition, because California courts have endorsed the use of fluid recovery in the class action context, Kraus may result in the channeling of much UCL litigation into class actions. ${ }^{19}$ Part II.B describes the UCL and contrasts UCL suits with class actions. Part II.C describes the concept of fluid recovery, and Part II.D examines the use of fluid recovery in class action and UCL litigation.

\section{A. Consumer Protection Through Class Action Litigation}

California has permitted class actions since the mid-nineteenth century. ${ }^{20}$ The California Code of Civil Procedure, enacted in 1872, allows for a class action "when the question is one of a common or general interest, of many persons, or when the parties are numerous, and it is impracticable to bring them all before the court." ${ }^{21}$ As this statutory language illustrates, one benefit of the class action device is that it provides an efficient mechanism for adjudicating multiple similar claims. ${ }^{22}$

18. See Wesley J. Howard, Note, Former Civil Code Section 3369: A Study in Judicial Interpretation, 30 HASTINGS L.J. 705 (1979) (expressing surprise at the fact that consumer advocates had not used the UCL more extensively in the past). However, as with the UCL, ethical and practical concerns have been raised regarding class actions. See, e.g., John C. Coffee, Jr., The Regulation of Entrepreneurial Litigation: Balancing Fairness and Efficiency in the Large Class Action, 54 U. CHI. L. REv. 877, 882-83 (1987) [hereinafter Coffee, Entepreneurial Litigation] (argumg that class actions are characterized by opportunistic behavior by plaintiffs' attorneys and asymmetric stakes, which leads to suits of dubious merit); John C. Coffee, Jr., Class Action Accountability: Reconciling Exit, Voice, and Loyalty in Representative Litigation, 100 CoLum. L. REv. 370, 371-72 (2000) [hereinafter Coffee, Class Action Accountability]. Coffee observes:

Where once [the class action] was viewed as empowering class members, increasingly it is seen as entrapping them. Correspondingly, where the plaintiffs' attorney was once seen as a public-regarding private attomey general, mcreasingly the more standard depiction is as a profit-seeking entrepreneur, capable of opportunistic actions and often willing to subordinate the mterests of class members to the attorney's own economic self-interest.

Id. (citation omitted).

19. See infra Part IV.A.1.

20. CAL. CIv. Proc. CoDE $\S 382$ (Deering $1991 \&$ Supp. 2002) (originally enacted in 1872).

21. Id.

22. See also Daar v. Yellow Cab Co., 433 P.2d 732, 746 (Cal. 1967). In Daar, a Los Angeles taxicab company was accused of systematically overcharging its customers. The plaintiff argued that the class should be certified because the percentage rate of overcharge was identical for cach class 
The goal of class action law in California is consumer protection through deterrence. ${ }^{23}$ Accordingly, it is not surprising that courts tend to favor class actions where the practices of a defendant affect large numbers of consumers but individual damage awards are too sinall to justify a private lawsuit. ${ }^{24}$ Without the class action, the illegal actor might retain the benefits of its wrongful conduct because no potential plaintiff would ever bring a lawsuit. ${ }^{25}$ Indeed, the Califonria Supreme Court recently has held that the probability that each class member will come forward to prove his or her separate claim to a portion of the total potential recovery inust factor in a court's decision on whether to certify a class. ${ }^{26}$

Traditionally, in dealing with consumer protection class actions, California courts have been friendly to plaintiffs' interests and willing to certify classes in situations where a federal court perhaps would not. ${ }^{27}$ However, despite the frequently iterated judicial support for consumer class actions, there are significant statutory and court-imposed barriers to maintaining a consumer protection lawsuit as a class action. For example, because the class representative must be a inember of the affected class, a consumer who is aware of an unfair business practice ${ }^{28}$ but who is not a direct victim of the practice cannot bring a class action..$^{29}$

Other significant barriers to consumer class actions are the expenses and inherent procedural complexities of class action litigation. For instance, consumer class actions are subject to certification by the court. ${ }^{30}$

member, each had sustained a loss because of the overcharges, and the amount of the overcharge easily could be determined from Yellow Cab's books and records. Id. at 737-38 nn.5, 7. The appellate court held that because a well-defined community of imterest in questions of law and fact existed, the consumer class action could proceed. Id. at 747.

23. See Linder v. Thrifty Oil Co., 2 P.3d 27, 31 (Cal. 2000). The California Supreme Court has held that deterrence is one of the key factors to be considered by courts in determining whether to certify a class. Id. See also Vasquez v. Superior Court, 484 P.2d 964, 968 (Cal. 1971) ("A class action by cousumers produces several salutary by-products, including a therapeutic effect upon those sellers who indulge in fraudulent practices...."). Cf. Fletcher v. Security Pacific Nat'l Bank, 591 P.2d 51, 56 (Cal. 1979) (observing that "[t]he requirement that a wrongdoing entity disgorge improperly obtained moneys surely serves as the prescribed strong deterrent" underlying the UCL).

24. See, e.g., Vasquez, 484 P.2d at 968-69; Richmond v. Dart Industries, Inc., 629 P.2d 23, 27 (Cal. 1981) (quoting Eisen v. Carlisle \& Jacquelin, 391 F.2d 555, 560 (2d Cir. 1968)) ("Class actions serve an important function in our judicial system.... [T] he class suit both eliminates the possibility of repetitious litigation and provides sinall claimants with a method of obtaining redress for claims which would otherwise be too small to warrant imdividual litigation."'); Daar, 433 P.2d at 746.

25. See Daar, 433 P.2d at 746.

26. Linder, 2 P.3d at 31. For an explanation of class certification, see infra notes 30-31 and accompanying text.

27. See Cartt v. Superior Court, 124 Cal. Rptr. 376, 383 n.17 (Ct. App. 1975) ("The apparent federal distaste for consumer class actions is not reflected in California.").

28. For simplicity, I will use the tern "unfair practice" to refer to all illegal, unfair or fraudulent business practices actionable under the UCL.

29. See James R. McCall et al., Greater Representation for California Consumers-Fluid Recovery, Consumer Trust Funds, and Representative Actions, 46 HAsrings L.J. 797, 804 (1995).

30. CaL. Crv. Code $\S 1781$ (c) (West 1998 \& Supp. 2002). Certification is an order by the court allowing the action to proceed as a class action. CAL. Civ. CODE $\$ 1781$ (b) (West 1998 \& Supp. 2002). 
This certification process can require extensive discovery and, consequently, formidable discovery expenses and a significant amount of the class attorneys' time. ${ }^{31}$ Furthermore, although California courts require only "meaningful notice" to all class members, ${ }^{32}$ courts still may order imdividual notice if they deem it necessary. ${ }^{33}$ Individual notice involves a mailing of forms to each potential class member, while meaningful notice may include such less expensive methods of constructive notice as newspaper or television advertisements. ${ }^{34}$ Bccause class action attorneys frequently work on a contingency basis, costs related to certification and notice may be prohibitive, and certain class actions may be stillborn as a result. ${ }^{35}$ Indeed, the very possibility of such prohibitive costs may function as a deterrent to bringing consumer class actions in California. ${ }^{36}$

\section{B. Consumer Protection Through the Unfair Competition Law}

To avoid the standing and procedural requirements of class action litigation, plaintiffs frequently bring consumer protection actions based on the Unfair Competition Law. ${ }^{37}$ The UCL prohibits "unfair competition," defined as "any unlawful, unfair or fraudulent" acts or practices, ${ }^{38}$ as well as false advertising. ${ }^{39}$ The statute is tremendously fiexible, and lacks such basic elements of proof as intent, reliance, or damages. A single instance of

31. McCall, supra note 29, at 803.

32. Cartt, 124 Cal. Rptr. at 386.

33. Individual notice may be ordered under either California Code of Civil Procedure Section 382 or Civil Code Section 1781(d). See Cal. Crv. Proc. CoDE $§ 382$ (Deering 1991 \& Supp. 2002); CAL. CIV. CoDe $\S 1781$ (d) (West 1998 \& Supp. 2002).

34. See CAL. CIv. CoDE $\S 1781$ (d) (West 1998 \& Supp. 2002) (permitting notice by newspaper publication "if personal notification is unreasonably expensive or it appears that all members of the class cannot be notified personally"). See also State v. Levi Strauss \& Co., 715 P.2d 564, 567-68 (Cal. 1986) (describing a major notification campaign including individual mailings and a two-week campaign of television and radio advertising in a price-fixing consumer class action).

35. In Cartt, the trial court ordered the plaintiff to notify, by first or third class mail, each of the 700,000 class members presently residing in Southern California at a cost of about $\$ 68,718$, an expense that is "quite out of the reach of plaintiff, who is a school teacher and earns less than $\$ 15,000$ a year." 124 Cal. Rptr. at 379-80.

36. California Civil Code Section 1781(d) provides that the cost of notice may be shifted to the defendant. CAL. CIv. CoDE $§ 1781$ (d). The California Supreme Court also has indicated that a trial court may shift such costs. See Civil Serv. Employees Ins. Co. v. Superior Court, 584 P.2d 497, 505-06 (Cal. 1978) (noting that cost-shifting promotes the legitimate public policy of encouraging class actions).

37. See Dean Witter Reynolds, Inc. v. Superior Court, 259 Cal. Rptr. 789, 799 (Ct. App. 1989) ("In contrast to the streamlined procedure expressly provided by the Legislature [for UCL actions], the management of a class action is "a difficult legal and administrative task.") (quoting Lazar v. Hertz Corp. 143 Cal. App. 3d 128, 143 (1983)). The very broad scope of relief available under the UCL may also make a UCL action more attractive to plaintiffs than a class action. See infra notes 48-65 and accompanying text.

38. Cal. Bus. \& Prof. Code $\S 17200$.

39. See CAL. Bus. \& Prof. CODE $\S \S 17500-17581$. 
an "unfair" practice under the UCL subjects a defendant to potential liability. ${ }^{40}$

The courts give an expansive interpretation to each of the three types of acts described by the phrase "unlawful, unfair, or fraudulent," leading the California Law Revision Commission to call the UCL "probably the broadest such statute in the country." 42 The broad interpretation of "unlawful" allows for recovery when the defendant has violated a statute that does not provide for a private right of action..$^{43}$ Under this interpretation, even a violation of a criminal statute can trigger a violation of the UCL. ${ }^{44}$ The expansive interpretation of "unfair" allows suit whenever harm to consumers outweighs the "utility of the defendant's conduct." 45 However, despite the apparent breadth and potential ambiguity encoinpassed by these terms, courts have rejected challenges to the UCL on vagueness grounds. ${ }^{46}$ Similarly, any business practice that is likely to deceive the public is actionable under the "fraudulent" prong of the UCL, which is a broader standard than the common law tort of fraud. ${ }^{47}$

Another aid to plaintiffs is that the scope of actionable conduct under the UCL is broader than that available in consumer protection class

40. See James Wheaton, California's Unfair Competition Law: The Biggest Hammer in the Tool Box?, ENvTL. L. NEws, Spring 2000, available at http://www.calbar.org/enviro/news/v09n2/ hammer.htm (last visited Mar. 9, 2002) ("Doctrines of standing, causation, and injury all vanish under Section 17200, leaving lawyers familiar with those doctrines ... in unfamiliar territory."). However, in Cortez v. Purolator Air Filtration Products Co., a companion case to Kraus, the California Supreme Court held that equitable defenses may be presented in UCL cases. 999 P.2d 706, 717 (Cal. 2000).

41. See generally Barquis v. Merchants Collection Ass'n, 496 P.2d 817 (Cal. 1972) (commenting on the broad nature of the UCL).

42. Cal. L. Revision Comm'n Rep., supra note 9, at 202.

43. The statute "'borrows' violations of other laws and treats these violations, when committed pursuant to business activity, as unlawful practices independently actionable under Section 17200 ...." Farmers Ins. Exch. v. Superior Court, 826 P.2d 730, 734 (Cal. 1992).

44. E.g., Stop Youth Addiction, Inc. v. Lucky Stores, Inc., 950 P.2d 1086 (Cal. 1998) (holding that a violation of a criminal statute prohibiting the sale of cigarettes to minors may give rise to a UCL action).

45. South Bay Chevrolet v. General Motors Acceptance Corp., 85 Cal. Rptr. 2d 30I, 316 (Ct. App. 1999). See also Saunders v. Superior Court, 33 Cal. Rptr. 2d 438, 441 (Ct. App. 1994) ('“Unfair' simply means any practice whose harm to the victim outweighs its benefits.") (citation omitted); People v. Casa Blanca Convalescent Homes, Inc., 206 Cal. Rptr. 164, 177 (Ct. App. 1984) ("[A]n unfair business practice occurs when it offends an established public policy or when the practice is immoral, unethical, oppressive, unscrupulous or substantially injurious to consumers."). The California Supreme Court criticized these "anorphous" definitions of unfairness and declared its own. In Cel-Tech Communications, Inc. v. Los Angeles Cellular Telephone Co., 973 P.2d 527 (Cal. 1999), it stated that under Section 17200, "unfair" means "conduct that threatens an incipient violation of an antitrust law, or violates the policy or spirit of one of those laws ... or otherwise significantly threatens or harms competition." Id. at 544. This definition, however, is limited to UCL suits alleging antitrust violations and is inapplicable to other actions under that statute. See id. at 544, n.12.

46. See People ex rel. Mosk v. Nat'l Research Co., 20 Cal. Rptr. 516, 521 (Dist. Ct. App. 1962) (holding that the UCL is not unconstitutionally void for vagneness).

47. See Saunders v. Superior Court, 33 Cal. Rptr. 2d 438, 441 (Ct. App. 1994). 
actions. ${ }^{48}$ For example, in Fletcher v. Security Pacific National Bank, the court held that restitution may be available under the UCL not only if the consumer has been harmed, but also if the challenged business practice is "likely to deceive." 49

Arguably, the sheer breadth of the statute dulls its purpose of consumer protection..$^{50}$ One commentator has noted that "[n]early every civil claim in California seems to include a cause of action under the UCL." $" 51$ Referring to such abuses of the statute, another commentator has observed: "The survey of cases and practitioners involved in Unfair Competition Law litigation indicates that ... it is currently functioning in a number of cases to frustrate the just and expeditious resolution of disputes." ${ }^{252}$ Similarly, Justice Brown has referred to the UCL as a "standardless, limitless, attorney fees machine." ${ }^{33}$ Indeed, many plaintiffs" attorneys have grown wealthy off the costs and fees reimbursement provisions of the UCL, ${ }^{54}$ while consumer fraud has not stopped.

Unlike the class action statute, the UCL confers broad standing to sue. ${ }^{55}$ The statute grants standing to the Attorney General, county district attorneys, and a number of other law enforcement personnel, ${ }^{56}$ as well as any person or entity acting for the interests of itself, its members, or the general public. ${ }^{57}$ In Barquis v. Merchants Collection Association, the California Supreme Court interpreted the statute to confer standing to sue even to a plaintiff uninjured by the allegedly illegal or unfair business

48. McCall, supra note 29, at 815 .

49. Fletcher, 591 P.2d at 57.

50. Cal. L. Revision Comm'n Rep., supra note 9, at 255 ("The breadth of the Act allows its inclusion as a cause of action in many business and consumer civil actions (private and public) brought on other bases.").

51. Shaye Diveley-Coyne, Who Needs Standing? Using California's Unfair Competition Law to Bring Federal Clean Water Act Claims in State Court, 7 Hastings W.-Nw. J. Envtl. L. \& PoL'Y 127, 137 (2001).

52. Cal. L. Revision Comm'n Rep., supra note 9, at 231. The expense of defending UCL actions is also an important complaint of the California business community. "[UCL] actions are becommg increasingly troublesome for many businesses. While the [UCL]'s remedies all sound in equity and seldom line the pockets of plaintiffs' attorneys, virtually anyone can bring a [UCL] action for virtually any reason, and the statute's provisions are so broad that pretrial dispositions are often difficult, although not impossible." Jonathan M. Jenkins, A Fair Deal, 22 L.A. LAw. 28, June 1999.

53. Stop Youth Addiction, Inc. v. Lucky Stores, Inc., 950 P.2d 1086, 1115 (Cal. I998) (Brown, J., dissenting).

54. Certainly, defense firms have also billed innumerable hours while defcnding UCL claims.

55. Joshua D. Taylor, supra note 13, at 1136 (observing "there is essentially no standing requirement for the UCL, as any plaintiff may file a suit-so long as they claim to be doing so in the interests of the general public"). Further, as noted by the California Supreme Court, the UCL extends "to the entire consuming public the protection once afforded only to business competitors." Barquis v. Merchants Collection Ass'n., 496 P.2d 817, 828 (Cal. 1972).

56. See CAL. Bus. \& Prof. Code $§$ I 7204 (West $1997 \&$ Supp. 2002).

57. Barquis, 496 P.2d at 828. 
practice. ${ }^{58}$ The lack of an individual injury requirement has led to UCL representative actions brought on behalf of the public by private individuals and, much to the dismay of the defense bar, even plaintiffs' lawyers acting as plaintiffs. ${ }^{59}$

Such plamtiffs, acting as "private attorneys general," may obtain class-wide relief without confronting the procedural technicalities of class action litigation. By express provision of the California legislature, individuals may use representative actions to obtain restitutionary relief ${ }^{60}$ without the pretrial notice and certification requirements of class actions. ${ }^{61}$ In fact, the court in Dean Witter Reynolds, Inc. v. Superior Court suggested that representative UCL actions should be favored because they avoid the complexity and expense of traditional class action litigation. ${ }^{62}$ In addition, without the notice and certification requirements of class actions, UCL suits may move inuch more swiftly to settlement or trial than class actions. As one commentator has noted, the UCL is "a boon for attorneys hoping to win a class action-type case and collect attorney fees without having to get a court to grant class-action status."

Another advantage for plaintiff's lawyers in filing UCL suits is that unlike class actions, private settlements of UCL actions only bind the individual who brought the action, not the entire plaintiff class. ${ }^{64}$ As a result, a

58. Id. at 817. See also Fletcher v. Security Pac. Nat'I Bank, 59I P.2d 5I, 57 (Cal. 1979) (holding that restitution may be available under the UCL not only when the consumer has been harmed, but also when the challenged business practice is "likely to deceive").

59. See Stop Youth Addiction v. Lucky Stores, 950 P.2d 1086 (Cal. 1998) (holding that a nonprofit organization coinposed of only one member, the attorney who brought the UCL suit, had standing to sue under the UCL).

60. The UCL allows only restitution, not damages. See infra note 77.

61. Dean Witter Reynolds, Inc. v. Superior Court, 259 Cal. Rptr. 789 (Ct. App. 1989).

62. Id. at 799.

63. Barbara M. Wheeler, Unfair Competition May Open Deep Pockets, Silicon VAlley / SAN Jose Bus. J., July 7, 2000, available at http://www.calbar.org/news/san_jose_bus_0700.html (last visited Mar. 9, 2002). Technically, the UCL does not provide for attorney fees, but a plaintiff pursuing a private attorney general suit may obtain litigation costs. CAL. Bus. \& PROF. CODE $\S 17206$ (a) (West 1997 \& Supp. 2002). However, UCL litigation can still be lucrative for attorneys. In one case, a court upheld as proper an award of $\$ 672,000$ in fees. HewIett v. Squaw Valley Ski Corp., 63 Cal. Rptr. 2d 118, I46 (Ct. App. 1997).

64. If a UCL case results in a judgment, as opposed to a settlement, another suit for restitution under the statute cannot seek restitution from the same defendant for the same wrongful misconduct occurring during the same time frame. Price v. Sixth Dist. Agric. Ass'n, 258 P. 387, 391-92 (Cal. 1927) (holding that res judicata bars representative actions brought to determine an issue of general public interest where the same issue of general public interest has already been addressed in a prior action brought by a different representative plaimtiff); Citizens for Open Access to Sand \& Tide, Inc. v. Seadrift Ass'n, 71 Cal. Rptr. 2d 77, 89-90 (Ct. App. 1998) (finding no imdication of a direct interest in the current dispute that was unrepresented in prior litigation); Gates v. Superior Court, $223 \mathrm{Cal}$. Rptr. 678, 682 (Ct. App. 1986) ("Judgments in representative taxpayer actions are binding on all other taxpayers even though the named taxpayer plaintiff in the second suit was not the same taxpayer who brought the original case."). However, most UCL actions settle, thereby leaving the defendant without the protection of res judicata. 
defendant who settles a UCL case may face additional litigation for the same unfair practice.

The favored remedy in UCL cases is disgorgement. In Fletcher, the California Supreme Court further stated that "the full impact of the deterrent force [of UCL remedies] is essential if adequate enforcement [of the law] is to be achieved. One requirement of such enforcement is a basic policy that those who have engaged in proscribed conduct surrender all profits flowing therefrom." ${ }^{95}$ Full disgorgement of profits, therefore, is an integral, and perhaps central, feature of a successful UCL action. ${ }^{66}$

Although fluid recovery provides an efficient method of disposing of disgorged funds, Kraus v. Trinity Management Services bars the use of fiuid recovery in representative actions under the UCL. ${ }^{67}$

\section{The Concept of Fluid Recovery}

Fluid recovery is a method of distributing the unclaimed or residue funds that remain after all class members have claimed their share of a damages award. ${ }^{68}$ Most frequently, under fluid recovery procedures, the portion of the damages award that cannot be distributed directly to individual class members is distributed in such a way as to put the residue to its "next best" use and to benefit as many class members as possible. ${ }^{69}$ The goal of fluid recovery is to make certain that the defendant disgorge all of its ill-gotten gains. ${ }^{70}$

Speciflc fluid recovery procedures include price rollback, escheat, and the establishment of a consumer trust fund. Under the price rollback concept, an amount equal to the unclaimed funds portion of the award is

65. Id. (quoting S.E.C. v. Golconda Mining Co., 327 F. Supp. 257, 259-60 (S.D.N.Y. 1971)) (internal quotations omitted). See also Bank of the West v. Superior Court, 833 P.2d 545, 553 (Cal. 1992) (stating that the purpose of the Section of the UCL that authorizes courts to order disgorgement is to deter future violations of the unfair practice and to foreclose retention by the violator of its illgotten gains).

66. The distinction between disgorgenent and restitution is as follows: the goal of disgorgennent is to take away unlawful gains, whereas the purpose of restitution is to distribute such gains to the direct victims of the practice. See infra notes 118-19 and accompanying text.

67. 999 P.2d at 721 .

68. See generally DeJarlais, supra note 4 . The creativity and flexibility of cy pres remedies appeal to many legal commentators. For an interesting application of the concept of fluid recovery to class action suits involving human rights violations, see Kathryn L. Boyd, Collective Rights Adjudication in U.S. Courts: Enforcing Human Rights at the Corporate Level, 1999 BYU L. REv. $1139,1187-88$.

69. See Note, Developments in the Law-Class Actions, 89 Harv. L. Rev. 1318, 1522 (1976) ("[W]here funds cannot be delivered precisely to those with primary legal claims, the money should if possible be put to the 'next best' use."). Settlements of class actions often include cy pres remedies. The most prominent example is the recent inulti-billion dollar tobacco settlement, which earmarked a large portion of the settlement for smoking prevention and other non-compensatory programs. To view the text of the settlement, see http://www.tobacco.neu.edu/smoke01.htm (last visited Mar. 9, 2002).

70. See Simer v. Rios, 661 F.2d 655, 676 (7th Cir. 1981) (holding that fluid recovery must be consistent with the goal of disgorgement, as well as deterrence and compensation). 
distributed by ordering a reduction of the price of the defendant's product until all of the ill-gotten gains are distributed back to the general consumer. ${ }^{71}$ Governmental escheat requires deposit of the residue into the state government's general fund. ${ }^{72}$ A consumer trust fund, also known as earmarked escheat, directs awarded funds to specific organizations that are in a position to use the funds for lawsuits, lobbying, or other projects aimed at benefiting class meinbers and those similarly situated. ${ }^{73}$ This method of fiuid recovery can take the form of either awarding a grant to an existing consumer protection organization or establishing a new organization. ${ }^{74}$

\section{Fluid Recovery Case Law in California ${ }^{75}$}

In 1993, the California Legislature expressly authorized einployment of a fluid recovery remedy in class actions. ${ }^{76}$ However, the legislature has not expressly authorized fiuid recovery in UCL actions. In Kraus, the court held that restitution to direct victims is the only monetary remedy available

71. See, e.g., Bebchick v. Public Utils. Comm'n, 318 F.2d 187, 203-04 (D.C. Cir. 1963) (per curiam), cert. denied, 373 U.S. 913 (1963) (revenues from improperly granted rate increase used to keep fares down on behalf of current transit riders). Price rollbacks are most appropriate where the defendant is a monopoly or offers products or services that are not easily substituted with others. Where a highly competitive market exists, however, a court-inandated price rollback inay have the counterproductive effect of gaining the offender greater market share and harming competition. In competitive markets, therefore, price rollbacks unust be minimal. This approach succeeds in keeping the market im balance, making the defendant disgorge his ill-gotten gains and allowing the public to benefit from lower prices.

72. DeJarlais, supra note 4 , at 751-53. The California Supreme Court has stated that unconditional escheat is the "least focused compensation" to class members, and should be regarded as a "last resort ... where a more precise remedy cannot be found." State v. Levi Strauss \& Co., 715 P.2d 564, 572 (Cal. 1986). Given that general escheat is disfavored by the highest state court, this Casenote will not discuss general escheat as a fluid recovery option.

73. The rationale is that the activities of such organizations promote the goals of consumer protection laws. See Granberry v. 1slay Invs., 889 P.2d 970, 977 (Cal. 1995) ("The propriety of Fluid Recovery $\mathrm{m}$ a particular case depends upon its usefulness in fulfillimg the purposes of the underlying cause of action.").

74. See generally DeJarlais, supra note 4, at 759-62.

75. The use of fluid recovery in federal courts has been limited, but not entirely absent. For example, in Eisen v. Carlisle \& Jacqueline, the Second Circuit stated that Rule 23 of the Federal Rules of Civil Procedure did not authorize the court to provide a cy pres remedy. 479 F.2d 1005, 1018 (2d Cir. 1972), vacated on other grounds, 417 U.S. 156 (1974). See also Fogie v. Thorn Ams., Inc., 190 F.3d 889 (8th Cir. 1999) (same); Weber v. Goodman, 1999 U.S. Dist. LEXIS 22832 (E.D.N.Y. May 26, 1998) (holding that fiuid recovery is premature until damage funds are fully distributed to direct victims); In re Matzo Food Prods. Litig., 156 F.R.D. 600 (D.N.J. 1994) (refusing to approve class settlement with only cy pres distribution). But see Jones v. National Distillers, 56 F. Supp. 2d 355 (S.D.N.Y. 1999) (allowing distribution to Legal Aid Society Civil Division despite "thin" ties to purpose of litigation fund); In re Wells Fargo Sec. Litig., 991 F. Supp. 1193 (N.D. Cal. 1998) (approving distribution to law school program instead of bar association); Dreman v. Van Ru Credit Corp., 1997 U.S. Dist. LEXIS 7776 (N.D. 11l. May 30, 1997) (allowing distribution to a legal aid foundation).

76. CAL. Civ. Proc. Code $§ 384$ (b) (Deering $1991 \&$ Supp. 2002). 
under the UCL. ${ }^{77}$ The following sections describe the history of judicial endorsement of fluid recovery in both class action litigation and UCL litigation.

\section{Class Actions}

The first use of fluid recovery in California occurred in a 1946 class action dealing with bus fare overcharges, Market Street Railway Co. $v$. Railroad Commission ${ }^{78}$ Knowing that few passengers would ever go to the trouble of claiming their small refunds, the court ordered that the residue fund be used for improvements to the railway system that would beneflt all passengers. The court reasoned that it was "free...to use broad discretion" in employing the fund in a way that would "avoid an unlawful or unjust result." $" 79$

In 1981, a California appellate court endorsed the use of fluid recovery. In Bruno v. Superior Court, ${ }^{80}$ the plaintiff class alleged price fixing by supermarkets selling milk and sought a total damage award for a class of milk-buying consumers. The plaintiffs requested allocation of unclaimed funds through a court order requiring defendants either to lower future milk prices or deposit the unclaimed funds with the state or a state agency for charitable purposes benefiting consumers. ${ }^{81}$ The appellate court held that each of the remedies was proper in a large class action involving small individual claims and that each was consistent with the purposes of the antitrust laws of preventing and punishing anti-competitive acts. ${ }^{82}$

In dicta, the Bruno court suggested that lowering future prices was a particularly appropriate way to handle a residue fund. The court noted that the likelihood of a double recovery or an unfair benefit to people uninjured by the defendant's acts does not bar the use of fluid recovery per se. ${ }^{83} \mathrm{Lim}$ iting its ruling to antitrust actions, the court held that "[i]f damages are distributed so as to substantially compensate the injured class members who have recovered the damages, and especially if that distribution serves to deter violations and disgorge illegal proflts, the letter and the spirit of antitrust law will have been obeyed." $" 84$

In 1986, the California Supreme Court for the first time expressly approved fluid recovery, in the Levi Strauss decision, albeit in dicta. ${ }^{85}$ Levi

77. The dissent in Kraus argued that the legislature may have intended to allow fluid recovery through the use of the courts' equitable power. Kraus v. Trinity Mgmt. Servs., Inc., 999 P.2d 718, 739 (Cal. 2000) (Werdegar, J., concurring \& dissenting).

78. 171 P.2d 875 (Cal. 1946).

79. Id. at 878 .

80. 179 Cal. Rptr. 342 (Ct. App. 1981).

81. Id. at 343 .

82. Id. at 349 .

83. Id. at 348 .

84. Id. at 349 .

85. State v. Levi Strauss \& Co., 715 P.2d 564, 570 (Cal. 1986). 
Strauss was another class action claiming violation of California antitrust law. The Attorney General, on behalf of the State of California and affected consumers, sought monetary relief for millions of California consumers that the defendant allegedly had overcharged for jeans in the early $1970 \mathrm{~s} .^{86}$ After lengthy litigation, the parties reached a settlement agreement under which Levi Strauss would pay $\$ 12.5$ million if the plaintiff class of over seven million affected consumers were certified. After the class certification, the Attorney General assumed the responsibility of distributing the funds to consumers who filed valid claims. The estimated recovery amount per pair of jeans was only thirty-five to forty cents. ${ }^{87}$ Due to the class action notice requirements, almost $\$ 2$ million of the settlement fund went toward notifying class members of their opportunity to claim some thirty cents per pair of jeans. ${ }^{88}$ Only 20 to $40 \%$ of the plaintiff class filed claim forms. ${ }^{39}$

Throughout the settlement and notification process, several intervenors challenged this approach, arguing that the court should establish a consumer trust fund with the settleinent money. They proposed administration of the fund by a nonprofit organization that would spend the settlement money on various consumer protection programs. Rejecting intervenors' arguments, the trial court approved the Attorney General's settlement proposal. The intervenors appealed and proposed a cy pres distribution of the residue funds only. ${ }^{90}$

Noting persuasive practical considerations and the amount of money already spent on notification and fund-claiming procedures, the supreme court affirmed the lower court's approval of the settleinent. Nevertheless, the court remanded the case, endorsing fluid recovery as an efficient and fair method of distributing unclaimed settleinent funds. ${ }^{91}$ In so holding, the high court appeared to be influenced by the intervenors' argument that creating a consumer trust fund would inake the benefits of the settlement available to silent class members as well as those who made a claim, ${ }^{92}$ while serving the goal of deterrence by promoting disgorgement of illgotten gains. ${ }^{93}$ The court criticized the widespread fraud in claim procedures and the expense of notiflcation efforts and expressed approval of the remedy inplemented in Market Street Railway, where nearly the entire fund was put to a cy pres use. Thus, the court seemed to suggest that in

\footnotetext{
86. Id. at 565 .

87. Id.

88. Id. at 569-70.

89. Id. at 575 .

90. Id. at 569 .
}

91. Id. at 576. The court expressed a desire that its decision would "serve as a source of guidance for both the trial court on remand and for other courts in confronting the largely uncharted area of fluid recovery in consumer class actions." Id.

92. Id. (noting that fluid recovery would address and protect the interests of the entire class).

93. See id. at 576 . 
major suits with small individual claims, a court could implement fluid recovery without even providing an opportunity for individual claims. ${ }^{94}$

The courts subsequently clarified and expanded on the Levi Strauss dicta in the context of class actions. One appellate court held that one of the prerequisites for fluid recovery is an ascertainable total amount of damages to the affected class, ${ }^{95}$ and another that the plaintiff must demonstrate that the defendant actually proflted from unfair practices. ${ }^{96}$ Another court concluded that the plaintiff should show that silent class members would actually benefit from the trust fund award to an organization. ${ }^{97}$

\section{Unfair Competition Law}

Arguably, the reasoning in Levi Strauss gives courts wide latitude to employ fluid recovery in representative UCL actions because in such cases it is often impossible to locate with certainty all victims of a particular unfair business practice. Accordingly, prior to Kraus, two appellate court decisions had endorsed the use of fluid recovery in UCL actions. In People ex rel. Smith v. Parkmerced Co., the trial court ordered the defendant landlord to refund unlawfully retained security deposits to all present and former tenants. ${ }^{98}$ Because it was impossible to locate some of the former tenants harmed by the landlord's illegal practices, the trial court ordered the unclaimed funds to be transferred to a tenants' rights organization. Noting that the legislature gave trial courts broad equitable powers to rectify unlawful busmess practices, the court of appeal affirmed the order. ${ }^{99}$ This case appears to be the first reported use of fluid recovery with a consumer trust fund in an individual representative action under the UCL.

The court of appeal also discussed and endorsed the use of fluid recovery in a representative UCL action in People v. Thomas Shelton Powers, M.D., Inc. ${ }^{100}$ There, the District Attorney charged that the defendants acted illegally in selling certain condominiums. The trial court agreed, holding the sales to be unfair business practices under the UCL. ${ }^{101}$ However, the trial court declined to permit fluid recovery, reasoning that it

94. According to the court, "it would serve no practical purpose to invalidate the settlement in this six-year-old class action. In a sense, this court is confronted with a fait accompli." Id. at 570 . Similarly, the court stated that "trial courts should have the full range of alternatives at their disposal." Id. at 576.

95. Collins v. Safeway Stores, Inc., 23I Cal. Rptr. 638, 644-45 (Ct. App. 1986).

96. See id. at 642-43; see also McCall, supra note 29, at 811 ("[The cy pres doctrine will not] cure deficient proof that the defcndant possesses funds that should be disgorged.").

97. See Six Mexican Workers v. Arizona Citrus Growers, 904 F.2d 1301, 1308 (9th Cir. 1990) (applying California law to strike down a proposed fluid recovery plan that did not adequately target the plaintiff class and that failed to provide sufficient supervision regarding distribution).

98. 244 Cal. Rptr. 22 (Ct. App. 1988).

99. Id. at 693.

100. 3 Cal. Rptr. 2 d 34 (Ct. App. 1992).

101. Id. at 37. 
did not have the power to order disgorgement of any funds that would not be restored to specific individuals harmed by the unfair business practice. ${ }^{102}$

The appellate court reversed, holding that the goal of deterrence of unfair or illegal business practices requires disgorgement of ill-gotten gains. Consequently, the court of appeal held that even if a victim of an unfair business practice is unidentifiable, and therefore direct restitution is impossible, a court may still order disgorgement of illegal profits. Citing the pro-consumer language of Market Street Railway, Levi Strauss, and Parkmerced, the court authorized the use of fluid recovery, including earmarked escheat, where victims of the practice could not be identified and compensated. ${ }^{103}$ The court strongly supported a model of recovery that benefits the public as a whole in addition to directly reimbursing victims of unfair business practices. Refiecting on the appellate opinions allowing fluid recovery, the court stated:

The cases did not turn on the ability to name specific persons as victims, but on the equities of preventing the defendant from benefiting from the illegal transaction and of reversing the harm of the wrongful act to the greatest extent possible. We see no reason to reach a different result here. ${ }^{104}$

In contrast to these cases, the Kraus court rejected a model of recovery that allows equitable remedies such as fluid recovery in consumer protection UCL actions.

\section{III \\ Case Statement \\ A. Trial Court and Appellate Decisions}

In Kraus v. Trinity Management Services, Inc., ${ }^{105}$ the California Supreme Court held that a court may not order disgorgement into a fluid recovery fund in a UCL action that is brought by a private party on behalf of absent persons and that is not certified as a class action. ${ }^{106}$

Plaintiff Vickey Kraus filed a representative action against Trinity Management Services, which owned and managed several rental properties in San Francisco. ${ }^{107}$ Alleging that defendants had assessed residential tenants unlawful non-refundable security deposits and administrative fees, the plaintiffs asserted various causes of action, including a UCL claim. ${ }^{108}$ After

102. Id.

103. Id. at 42 .

104. Id.

105. 999 P.2d 718 (Cal. 2000).

106. Id. at 721 .

107. Id. at 722 .

108. Id. at 722 . 
finding for the plaintiffs, the trial court ordered the defendants to use due diligence for ninety days to locate and reimburse all present and former tenants who had paid the unlawful deposits, ${ }^{109}$ and to place the residual funds in a trust fund to provide financial support for the advancement of legal rights and interests of residential tenants in San Francisco. ${ }^{110}$ The court made this order for fluid recovery over the express objection of the defendants that the remedy was not available in UCL lawsuits. ${ }^{111}$

The court of appeal held that the UCL authorizes an order for disgorgement and/or restitution as relief ancillary to an injunction against an unfair trade practice, and that a trial court, by its equitable powers, may provide for payment into a fluid recovery fund. ${ }^{112}$ The court held that it was for cases like this that the legislature explicitly had created a streamlined procedure by which to challenge unfair business practices where a class action is mappropriate. ${ }^{113}$ Consequently, the court of appeal concluded that the trial court was not required to certify this action as a class action before ordering fluid recovery. ${ }^{114}$

\section{B. California Supreme Court Decision}

The California Supreine Court reversed. Writing for the majority, Justice Baxter distinguished between disgorgement and restitution in the context of an action under the UCL. ${ }^{115}$ Restitution, the court explained, involves restoring to a particular victim unjust profit taken by the defendant, and is expressly authorized by the UCL. ${ }^{116}$ Disgorgenent, on the other hand, occurs when a court takes away all of a defendant's profits resulting from an unfair practice without regard to whether there is a particular victim to whom the unjust profits should be paid. ${ }^{117}$

The court explained that when the legislature added restitution to the list of UCL remedies in the 1970s, the courts had not yet established fiuid recovery as an appropriate method of relief in class actions, and that the legislature therefore could not possibly have intended fluid recoveries in UCL actions. ${ }^{118}$ Justice Baxter supported this conclusion by pointing out that when the legislature subsequently endorsed fluid recovery in class actions in 1993, it did not add similar language extending fiuid recovery to a

109. Id. at 723.

110. Id.

111. Id.

112. Id. at 723-24.

113. Id. at 724 .

114. Id.

115. Id. at 725 .

116. Id.

117. Id.

118. Id. at 732 . 
representative action under the UCL. ${ }^{119}$ Accordingly, the court held that the UCL "does not authorize orders for disgorgement into a fluid recovery fund," 120 thus overruling Powers and Parkmerced. The high court held that unless a plaintiff maintains its UCL action as a class action, restitution is the only monetary relief available. ${ }^{121}$

In contrast to its rejection of fluid recovery in a representative action under the UCL, the court unequivocally approved the use of restitution in such actions to non-plamtiff consumers injured by an unfair practice. ${ }^{122}$ The court also imposed a signiflcant burden on defendants to complete this restitution, stating that "the trial court should order defendants to identify, locate, and repay [consumers affected by the unfair practice] the full amount of funds improperly acquired [from those consumers], retaining the power to supervise defendants' efforts, to ensure that all reasonable means are used to comply with the court's directives." 123

In response to the defendant's due process arguments, Justice Baxter first observed that if a defendant had already paid restitution to an individual claimant, the defendant could present evidence of such payment to avoid paying twice. ${ }^{124}$ The court further rebuffed the defendant's due process contentions by noting that the likelihood that any former tenants could overcome the statute of limitations was too remote in this case. ${ }^{125}$ However, the high court did emphasize that courts may dispose of representative suits based on a defendant's showing either of "potential for harm"126 or that the action is not brought by a "competent plaintiff" for the benefit of injured parties. ${ }^{127}$ Fimally, in a victory for busmess defendants, the California Supreme Court suggested that a trial court may condition the payment of restitution to the plamtiffs on the signing of a release of all claims, and thus prevent repetitive actions stemming from the same course of illegal conduct. $^{128}$

119. Id. ("In sum, the Legislature has not expressly authorized monetary relief other than restitution in UCL actions, but has authorized disgorgement into a fluid recovery fund in class actions.").

120. Id.

121. Id.

122. Id.

123. Id. (footnote omitted).

124. Id. at 732-33.

125. Id. at 733. See also Lees, supra note 12. Lees observes:

[P]erhaps because a inajority of the court was unwilling to embrace the due process arguments put forward by defendants and their amici, Justice Baxter focused on the peculiar facts in Kraus, a case involving a small number of victims of an unlawful practice that already had gone to trial and made its way through a lengthy appeal.

Id.

126. Kraus, 999 P.2d at 733.

127. Id. The court left these crucial terms undefined, thus giving wide interpretive latitude to lower courts.

128. Id. at 732 . 


\section{THe NeED For a Legislative ReJoINDER to KRAUS}

The Kraus court based its holding on indirect evidence of legislative intent. Specifically, it concluded that the legislature did not intend to permit fluid recovery under the UCL because it enacted a provision in 1993 to expressly provide for fluid recovery in class actions but did not enact a corresponding provision for the UCL. This Casenote does not employ the tools of statutory interpretation to evaluate the California Supreme Court's narrow view of the UCL in Kraus. ${ }^{129}$ Rather, this Casenote focuses on the practical consequences of Kraus and the desirability of fluid recovery in UCL actions. This Casenote argues that Kraus threatens to undermine the UCL's broad remedial goals and that the legislature therefore should respond to Kraus by amending the UCL to allow fluid recovery.

\section{A. The Problems Created by Kraus}

The Kraus decision is too recent for an examination of its actual consequences. The impact of Kraus will be complex and multifaceted. Some commentators argue that Kraus strikes a blow against consumer protection litigation in California, ${ }^{130}$ while others maintain that under appropriate circumstances, its impact may be minimized. ${ }^{131}$ What is certain is that the decision opened a new chapter in consumer protection litigation in California. This section considers the expected legal and practical consequences of Kraus.

129. In Kraus, the majority and the dissent made strong arguments employing statutory history on both sides of the issue. The majority stated that where "the language of a statute is clear and unambiguous, judicial construction is not necessary and a court should not indulge in it." 999 P.2d at 726 (citation omitted). It also noted that the Legislature's failure to amend the UCL to allow fluid recovery where it had done so with the class action statute evidenced its intent to deny fluid recovery under the UCL. Id. at 732. The dissent, on the other hand, argued in some detail that neither the language, nor the history, nor the spirit of the UCL justified such "fallacious reasoning." Id. at 736 (Werdegar, J., concurring \& dissenting). This split illustrates the messy state of statutory interpretation today. See generally William N. Eskridge, Jr. \& Philip P. Frickey, Statutory Interpretation as Practical Reasoning, 42 STAN. L. Rev. 321 (1990); J. Clark Kelso \& Charles D. Kelso, Statutory Interpretation: Four Theories in Disarray, 53 SMU L. REv. 81 (2000).

130. John H. Sullivan, president of the Civil Justice Association of California, noted that " [c]ertainly some of the wind has been taken out of the sails of private lawyers trying to use the Unfair Competition Law to fund their enterprises." Civil Justice Ass'n of Cal., Statement on Today's Decisions by the California Supreme Court in Two Unfair Competition Law Cases, at http://www.cjac.org/news/060500.html (last visited Mar. 9, 2002). Cf. J. Clark Kelso, A Healthy Balance of Decisions, CAL. B.J., Oct. 2000, available at http://www.calbar.org/2cbj/00oct/pagel-1.htm (last visited Mar. 9, 2002) (noting that Kraus will make it more difficult for plaintiffs to use the UCL as an altemative to class action litigation).

131. See generally Brad Seligman \& Jocelyn Larkin, Fluid Recovery and Cy Pres: A Funding Source for Legal Services, Impact Fund, http:/www.impactfund.org/CyPres2000CA.htm (last visited Mar. 9, 2002). One commentator suggests that Kraus may be a blessing in disguise for consumer protection advocates. See Diveley-Coyne, supra note 51, at 137 (arguing that "by using the UCL appropriately and sparingly, citizen-groups may minimize the scrutiny of so-called 'reformers' and protect the law's unique benefits"). 


\section{Channeling of UCL-type Claims to Class Action Litigation}

The defining feature of the UCL is the breadth of consumer protection it offers, as reflected in its expansive approach to standing and procedure. Although the UCL strikes many as too far-reaching, its breadth has allowed plaintiffs to prosecute a remarkably wide variety of unfair practices without the hurdles of class action litigation. ${ }^{132}$ However, after Kraus, many California consumers will be left with the costly and procedurally cumbersome device of the class action as their most viable type of court action. Furthermore, the class action's rigorous standing requirement may foreclose even the class action option to nany consumers who would have had standing under the UCL. In addition, as a result of Kraus, those consumers who choose to pursue actions under the UCL will face new obstacles, such as the ambiguous "coinpetent plaintiff" standing requirement. These practical effects of the Kraus decision undermine the UCL's goals of consumer protection.

By abolishing fluid recovery under the UCL, Kraus will limit representative UCL actions where the injured parties are not readily identifiable or where they are unlikely to claim restitution benefits. ${ }^{133}$ This effect will be most apparent in cases where the unfair practices are unusually widespread or where damage to the individual consumer is insubstantial. If plaintiffs pursue court action at all in such cases, they are likely to bring class actions rather than UCL actions because fiuid recovery remains available in class actions. ${ }^{134}$ However, because the procedural hurdles and upfront expenses required in class action litigation can deter the filing of such actions, ${ }^{135}$ after Kraus, some injurious business practices may go wholly unchallenged.

Of course, California's courts historically have been sympathetic to consumer protection actions, and therefore might apply leniently the class action certification requirements im lawsuits involving unfair practices. Although such judicial lenience could soften some of the negative

132. For the outer reaches of litigation over unfair practices, see supra note 13.

133. In such cases the settlement value of the suits is also likely to decrease. Where previously the threat of fluid recovery encouraged defendants to settle, after Kraus there is less incentive to do so.

134. As a spokesperson for the Consumers Union commented after Kraus, the ruling is a "setback for consumers" because California consumers will now have to file a class action suit in order to disgorge all gains from an unfair practice. Sheila Muto, High Court Ends 'Recovery Funds' for Consumers, WALL ST. J., June 7, 2000, at CA-2. See also California Supreme Court Decides Unfair Competition Issues in Kraus v. Trinity Management Services and Cortez v. Purolator Air Filtration Products, Latham \& Watkins Pubs. Client Alert, Litig. Dep't Bulletin No. 114, July 17, 2000, http://www.lw.com/pubs/clientAlert/htm/alert1 14.htm (last visited Mar. 9, 2002):

As a practical matter, defendants' liability for straight UCL clainis may well be reduced under [Kraus], as defendants will not be required to pay for restitution that is not actually claimed. On the other hand, this limitation may simply encourage plaintiffs to file more class actions or amend existing UCL cases to add class allegations, if possible. 
consequences of channeling consumer litigation into class actions, it still would not help consumers who could have benefited from the UCL's extremely broad standing provision. While almost anyone can bring a UCL action, a class action plaintiff must be a member of the affected class. ${ }^{136}$ This is significant because a consumer who is aware of an unfair practice but who is not a direct victim of the practice can bring an action under the UCL, but cannot act as a plaintiff in a class action. Accordingly, after Kraus, consumer protection suits that are likely to require fluid recovery cannot be brought by public organizations, crusading attorneys, or other persons who have not been directly injured by an unfair practice.

When plaintiffs cannot afford the time or expense of class certiflcation, or when they do not meet the standing requirements of a class action, they may file a UCL action seeking injunctive relief, thereby foregoing the opportunity to seek fluid recovery. ${ }^{137}$ However, with remedies limited to injunctive relief and attorneys' fees in some cases, the prospect of UCL litigation may not have sufficient deterrent effect. ${ }^{138}$

Further, even under the UCL, plaintiffs will face new obstacles as a result of Kraus. For instance, Kraus appeared to impose a vague requirement that the action be brought by "a competent plaintiff for the benefit of injured parties." 139 The Kraus court declined to elaborate on this potentially thorny standard, but it appears that this language allows the court to employ a class action-type adequacy test to deternme whether a plaintiff is "competent." $" 140$ In addition, in cases where the alleged victims are unlikely

136. See supra Parts II.A-B. See also Bartlett v. Hawaiian Village, Inc., 151 Cal. Rptr. 392, 394 (Ct. App. 1978) (holding that the class action plaintiff must be "truly representative of the absent, unnamed class meinbers"); Payne v. United Cal. Bank, 100 Cal. Rptr. 672, 679 (Ct. App. 1972).

137. See McCutchen Update: California Supreme Court Limits Disgorgement Remedy Under Unfair Coinpetition Law, McCutchen, Doyle, Brown \& Enersen, LLP, Envt'l \& Land Use, June 6, 2000, http://www.nccutchen.com/are/env/env_upd_Krause_cortez.htm (last visited Mar. 9, 2002):

The time and expense of class certification may mean that some plaintiffs will not seek class certification-and thus will forego seeking defendants' disgorgement into fluid rccovery funds. With remedies limited to injunctions and attorney's fees, the stakes in such future Section 17200 cases may be lower for soine defendants.

Id.

138. See Susan Beth Farmer, More Lessons From the Laboratories: Cy Pres Distributions in Parens Patriae Antitrust Actions Brought by State Attorneys General, 68 FoRdHAM L. REv. 361, 406 (1999) ("[U]se of a cy pres remedy for the entire corpus of a settlement or damages fund may serve, in effect, as a civil penalty that is likely a stronger deterrent than injunctive relief alone ...."). See also McCutchen, supra note 137.

139. Kraus v. Trinity Mgmt. Servs., Inc., 999 P.2d 718, 733 (Cal. 2000).

140. As observed by one commentator, "[i]t is not entirely clear what the majority meant by 'competent,' but it might fairly be supposed to refer to the same sort of nnanageability concerns that troubled the appellate court in an carlier UCL case, Bronco Wine Co. v Frank A. Logoluso Farms [citation]." William L. Stern, Keeping Score: A Reader's Guide to Kraus and Cortez, 22 Civil Lirig. ReP. 198, 199 (2000). See Bronco Wine Co. v. Frank A. Logoluso Farms, 262 Cal. Rptr. 899 (Ct. App. 1989) (reversing a trial court's order of restitution to the nonparties in a UCL action because of the potential for due process abuses and noting "management problems associated with awarding judgments for or against nonparties not subject to the court's jurisdiction"). 
to be identified and located, defendants may argue that the suit is not for the benefit of injured parties. Thus, after Kraus, plaimtiffs should expect to face new and vigorous challenges to the propriety of their lawsuits.

Admittedly, the restrictions set forth in Kraus will limit litigation, and thus give California businesses a bit more breathing rooin. Moreover, just as more litigation does not necessarily result in greater consumer protection, a decrease in litigation will not inevitably lead to inore unfair practices. Still, when consumer suits are channeled into class actions, realization of the benefits intended by the legislature in enacting the UCL often may be impossible. Instead of a streamlined procedure for challenging unfair business practices, Kraus leaves many California consumers with the costly and procedurally complicated device of the class action as their only option.

\section{Imposition of an Inefficient Restitution Burden on Defendants}

The Kraus decision imposes a restitution requirement that both shortchanges the public and unduly pumishes defendants. Despite language to the contrary, Kraus creates a conceptual gap between the previously congruent aims of restitution and disgorgeinent. Although Justice Baxter recognized that the court inay order disgorgeinent because that reinedy has greater deterrent effect than an injunction, ${ }^{141}$ the court held that "restitution is the only monetary remedy expressly authorized by section 17203."142 Thus, in the context of large consumer protection actions where direct victims may be impossible to locate, the fate of unclaimed disgorged funds is unclear. If the only alternatives to restitution are escheat to the state or retention of funds by the defendants, the benefit to the consuming public, as envisioned by the $\mathrm{UCL}$, is negligible.

Presumably, all ill-gotten funds will be restored to the victims of the practice. The Kraus court held that in successful UCL actions, the trial court should order defendants to "identify, locate and repay" each absent injured party the full amount of funds improperly acquired from him, and that such trial courts wonld retain "the power to supervise the defendants' efforts to ensure that all reasonable means are used to comply with the court's directives." ${ }^{143}$ However, this direct restitution requirement is costly, burdensome, and, in cases where individual claims are small, incongruous with its benefits and arguably wasteful. ${ }^{144}$

Given the facts of Kraus, the court's imposition of notice and claim administration requirements on the defendant was not unreasonable. The

141. Kraus, 999 P.2d at 732 .

142. Id. at 726 .

143. Id. at 732 (footnote omitted).

144. The direct restitution requirement is wasteful regardless of whether it is the plaintiff or defendant who funds the effort to identify and locate every victim. 
defendant property management company presumably had contact information for former tenants and could therefore locate them without great effort or expense. ${ }^{145}$ However, the Kraus court failed to consider the implications of its decision for situations where identifying and locating potential claimants would be extremely difficult or unduly expensive. The court's use of "reasonable means" language is meaningless in consumer protection cases potentially involving thousands or even millions of direct victims.

For example, consider Vasquez v. Avco Financial Services, ${ }^{146}$ a case involving unlawful "flipping" of retail purchase imstallment loans. ${ }^{147}$ In Vasquez, the defendant's unfair practice affected more than 125,000 customers throughout California. ${ }^{148}$ After the trial court directed Avco to make restitution to its customers, $60 \%$ of the disgorged funds remamed unclaimed because many former customers could not be located without undue expense. ${ }^{149}$ Faced with an excess fund of approximately $\$$ I.4 million, the parties agreed to employ a cy pres remedy. ${ }^{150}$ According to the stipulation, the Consumers Union received the fund for research, litigation, legislative advocacy, administrative advocacy, and education $i m$ the areas of consumer credit and flnance. ${ }^{151}$ Thus, although the unreachable class members were not reimbursed, similarly situated individuals in the public at large benefited from the funding of consumer protection programs. After Kraus, however, the trial court would face the Hobson's choice of allowing the defendant to retain unclaimed ill-gotten funds or ordering fluid recovery at risk of reversal by an appellate court. ${ }^{152}$

Not only does Kraus create a Hobson's choice for trial courts faced with substantial unclaimed funds in a UCL action, but its notice requirement also imposes an undue burden on defendants. Consider the following hypothetical: a plaintiff brings a successful representative UCL suit against a supermarket chain that had rigged its scales to overcharge its

145. The Kraus court, along with many others, employed the hoary legal fiction that victims of the practice would actually understand their claim notice. See, e.g., Arthur R. Miller \& David Crump, Jurisdiction and Choice of Law in Multistate Class Actions After Phillips Petroleum Co. v. Shutts, 96 YALE L.J. 1, $22 \&$ n.162 (1986) (arguing that the U.S. Supreme Court's rulmg in the title case depended on the erroneous assumption that class action notices are intelligible to the average person, and giving examples of profoundly confused responses to a pharmaceutical class action notice).

146. No. NCC-1 1933-B (L.A. Super. Ct. Apr. 24, 1984).

147. See McCall, supra note 29, at $845-49$ (discussing Vasquez). "Flipping" is "the conversion by a holder of a retail installment sales account into what was termed a new loan." Id. at 845 .

148. Id. at 847-48.

149. For a more detailed description of the Vazquez cy pres fund, see id. at 848 .

150. Id. at 848 .

151. Id. at $848-49$.

152. Some direct victims may never be locatcd. See Kraus v. Trinity Mgmt. Scrvs., Inc., 999 P.2d 718, 740 (Cal. 2000) (Werdegar, J. dissenting) (citing Parkmerced for the proposition that "[a]ppropriate interested parties may not be individually identifiable, or identifiable at the time disgorgement is ordered"). 
customers by about a dime per purchase. Customers who paid cash will be utterly unidentifiable and, therefore, unreachable. However, even if all overcharged consumers could be located through the credit cards and discount cards they used to make their purchases, it is not clear whether the benefit of locating them is worth the cost. Compare this hypothetical notification and restitution scenario with Vazquez, where the defendants had access to their own consumer records to locate claimants. ${ }^{153}$ Despite this ready access, the notification effort in Vasquez cost a quarter of a million dollars, and left many former Avco customers unreachable without "undue expense." ${ }^{154}$ Presumably, that price tag would be much higher in situations such as the supermarket hypothetical where purchase imformation data has to be sorted and analyzed at considerable expense even before the defendant can undertake the onerous task of notifying customers of their entitlement to a few dimes. Adjusting for inflation since Vasquez, and considering the sheer scope of the process, the cost of notification in the supermarket hypothetical easily could reach tens of millions of dollars. ${ }^{155}$

Significantly, Kraus allows courts to place this potentially astronomical financial burden of notification on the defendant's shoulders. ${ }^{156}$ The reasonableness and practicality of this approach are not apparent, to say the least. For example, in the supermarket hypothetical, administration of restitution may cost the defendant many times more than disgorging the remaining ill-gotten gains. ${ }^{157}$ This outcome, sanctioned by Kraus, seems inconsistent with the fact that the legislature declined to permit punitive damages against UCL defendants. ${ }^{158}$ While the costs of locating and

153. McCall, supra note 29 , at 848.

154. The court also ordered Avco to pay for monitoring of the refund process by accountants, at a cost in excess of $\$ 250,000$. McCall, supra note 29 , at 848 .

155. Conceivably, new advances in technology may reduce the burden imposed by notification. For instance, notification costs could be reduced if the class of plaintiffs is contacted by e-mail. See Jennifer Mingus, Note, E-Mail: A Constitutional (and Economical) Method of Transmitting Class Action Notice, 47 CLEV. ST. L. REV. 87 (1999). This practice, however, is not yet commonplace.

156. See Kraus, 999 P.2d at 732 n.18. The Kraus court observed:

Because an order to disgorge into a fluid recovery fund is not authorized in such representative UCL actions, the trial court may order the defendant to notify the absent persons on whose behalf the action is prosecuted of their right to make a claim for restitution, establish a reasonable time within which such claims inust be made to the defendant, and retain jurisdiction to adjudicate any disputes over entitlement to and the amount of restitution to be paid.

Id

Interestingly, the Court used the word "may" and not "shall" in making this pronouncement. Therefore, it is entirely possible that at least some trial courts will order the plaintiff (or rather his lawyer) to shoulder some of the costs. The possibility of such an order may put a damper on consumer protection litigation where individual claims are sinall.

157. In addition, as the cost of losing such a suit threatens to rise to astronomical proportions, defendants may face exorbitant settleinent demands.

158. See CAL. Bus. \& Prof. Code $§ 17203$ (West 1997 \& Supp. 2002) (limiting remedies to restitution). Of course, the trial court could have ordered full plaintiff class notification even before Kraus through a legitimate exercise of its equitable powers. See Kraus, 999 P.2d at 738 (Werdegar, J. 
refunding consumers in cases similar to the supermarket hypothetical are not true punitive damages, they approach the level of some multi-milliondollar punitive damages awards. Thus, the defendants' exposure to nonrestitution damages may approach levels not foreseen by the legislature, which, in passing the UCL, emphatically rejected any damages other than restitution.

\section{Restriction of Courts' Equitable Powers Under the UCL}

Remedies under the UCL are equitable. ${ }^{159}$ Traditionally, California courts have had wide latitude in defining "unfairness" and im fashioning relief under the UCL. However, Kraus involved a trial court's unusually broad application of cy pres without a sufficient attempt to reimburse direct victims of the defendant's unfair practices. When the California Supreme Court reacted to this apparent abuse of judicial power by barring the courts' equitable powers to fashion cy pres remedies, it set a dangerous precedent: future defendants may use Kraus to convince trial courts that their equitable powers under the UCL are greatly limited.

California jurisprudence has long emphasized the importance of the courts' equitable power in implementing the UCL's mandate against unfair practices. In 1935, the California Supreme Court declared that the breadth of the law permits the courts to enjoin ongoing wrongful busmess conduct in a variety of contexts and enables them to provide remedy for countless "new schemes which the fertility of man's invention would contrive." 160 Similarly, in 1972, the court reasoned in Barquis that "[i]n permitting the restraining of all 'unfair' business practices, [the UCL] undeniably establishes only a wide standard to guide courts of equity.... [G]iven the creative nature of the scheming mind, the Legislature evidently concluded that a less inclusive standard would not be adequate."161

Guided by this broad interpretation of the UCL, California courts have been able to thwart a wide range of unfair practices and fashion creative relief plans. Indeed, a broad interpretation of courts' equitable powers under the UCL supported the use of fiuid recovery in cases such as Powers and Parkmerced. ${ }^{162}$ Before Kraus, however, no court had ever directed payment of the restitutionary award resulting from a UCL action into a fluid recovery fund without a comprehensive effort to restore money to the

dissenting) ("Under existing precedent ... courts have discretion to require class-action-like procedures in particular UCL matters, although they are not required to do so."). The disturbing hypothetical that I am setting out, however, differs in one important respect: after Kraus, full class notification is mandatory. The option of rejecting this approach as unduly expensive is no longer available.

159. See, e.g., Desert Healthcare Dist. v. Pacificare, FHP, Inc., 114 Cal. Rptr. 2d 623, 632-34 (Ct. App. 2001) (stating that remedies under the UCL are largely equitable im nature).

160. American Philatelic Soc'y v. Claibourne, 46 P.2d 135, 140 (Cal. 1935).

161. Barquis v. Merch. Collection Ass'n, 496 P.2d 817, 830 (Cal. 1972) (internal citations omitted).

162. See supra Part II.D.2. 
actual victims of the unfair practice. Previous cases had allowed payment into a fluid recovery fund only where there were no specific victims, or where some funds were left unclaimed after victims who could be located recovered their money. ${ }^{163}$

The trial court in Kraus probably erred in allowing only a limited ninety-day due diligence effort to find the affected parties before ordering placement of the residue in a fluid recovery fund. As a result of this limited effort, affected individuals who could be found in a period of just over ninety days would be unable to claim refunds that were rightfully theirs. Indeed, given the lack of a notice requirement in UCL actions, ${ }^{164}$ this outcome is highly probable. Accordingly, the lower court's implenentation of its fluid recovery solution was inconsistent with the traditional inethod of fluid recovery advocated in California, which perınits funds to be put to the "next best use" only after every effort has been inade to compensate the actual victims. ${ }^{165}$ Given the courts' past emphasis on the importance of restitution to direct victims in UCL actions, this essential difference between Kraus and the cases that preceded it inakes Kraus a poor test bed for evaluating the propriety of fluid recovery in UCL actions. ${ }^{166}$

Faced with the trial court's inappropriate implementation of fluid recovery, the California Supreme Court reacted by eliminating the courts' equitable power to permit fluid recovery in UCL actions altogether. However, the issue on appeal was not whether fluid recovery is inappropriate per se, but whether courts have the power under the UCL to order it. ${ }^{167}$ Thus, the high court was faced with a broader concern over the extent of a trial court's power in adjudicating UCL claims, an issue of particular importance to business defendants. In Kraus, the California Supreme Court gave defendants important precedent for arguing that lower courts inust refrain froin fashioning relief in ways that may be fair or practical but not clearly authorized by the language of the statute. ${ }^{168}$ Indeed, the dissent correctly perceived the real implications of the decision:

163. People v. Thomas Shelton Powers, M.D., Inc., 3 CaL. Rptr. 2d 34, 42-43 (Ct. App. 1992); People ex rel. Smith v. Parkmerced Co., 244 Cal.Rptr. 22, 26-27 (Ct. App. 1988).

164. See supra Part II.B. In a class action proceeding, by contrast, potential claimants would receive notice of the lawsuit and would have the opportunity to come forward and show their entitlement to recovery in a particular amount. See, e.g., State of California v. Levi Strauss \& Co., 715 P.2d 564, 567-69 (Cal. 1986).

165. Levi Strauss, 715 P.2d at 570-71.

166. As stated by the Kraus court, "The second step of the procedure for implementation of fluid recovery ... permits class members to collect their share of the recovery. The judgment in this case does not expressly provide for any restitution of liquidated damage/security fee payinents to tenants." Kraus v. Trinity Mgmt. Servs., Inc., 999 P.2d 718, 723 n.6 (Cal. 2000) (citations omitted).

167. Id. at 723 .

168. See id. at 732. The court observed:

Notwithstanding the absence of legislative or other authority for the use of a fluid recovery remedy in a representative UCL action, the Court of Appeal here concluded that such orders 
[A]ny rigid restriction on fluid recovery such as the majority announces today ... will severely limit the remedies available in a critical class of UCL actions-those brought by personally unaggrieved plaintiffs .... [W] should retain a flexible construction of section 17203, permitting trial courts to countenance the full range of equitable and statutory UCL remedies, including in appropriate cases cy pres fluid recovery, even absent class certification .... [N]othing in section 17203-or anywhere else in the UCL-suggests the Legislature's use of the phrase "any person in interest" $(\$ 17203)$ was intended to restrict a court's inherent equitable powers when crafting UCL remedies. ${ }^{169}$

Thus, as the law school mantra goes, "extreme cases make bad law." As a result of Kraus, business defendants will argue that California courts do not have authority to implement any equitable remedies not clearly authorized by the statute. This narrow view of the courts' equitable powers under the UCL will undermine the statute's broad remedial goals.

\section{B. The Merits of Fluid Recovery}

The Supreme Court's rejection of fluid recovery in UCL actions will stand unless the legislature amcnds the statute. This section presents several reasons for doing so, while examining how fluid recovery can benefit both businesses and consumers.

\section{Furtherance of the UCL's Goals Even Where Restitution Is Impossible or Impractical}

Ideally, every victim of an unfair business practice would get restitution. In the context of mass litigation, however, that ideal is unattainable and should be abandoned. ${ }^{170}$ Although restitution should be made where possible and practical, fluid recovery offers a way to employ the disgorged funds in a manner that benefits the consuming public as a whole. This section argues that fluid recovery is congruent with the UCL's history and ambitious goals, and that the modern trend of pragmatism in mass litigation strongly supports non-restitutionary models of recovery.

are within the broad equitable powers of the court when deemed necessary to deter employment of unfair practices in the future. Id.

169. Id. at 739 (Werdegar, J., concurring \& dissenting).

170. In UCL actions concerning business practices affecting large numbers of people, there will almost inevitably remain excess funds. Farmer, supra note I38, at 393 ("In aetions on behalf of a very large number of class members, especially if eaeh has a relatively small claim, excess funds typically remain after the distribution of any settlement or judgment because elass members remain unidentified, unidentifiable, or simply fail to seek their share of the fund."). 


\section{a. Fluid Recovery Is Consistent with the Broad Goals of the UCL}

By definition, a fluid recovery fund only exists when some direct victims of an unfair practice remain uncompensated. As explained above, in Kraus, the California Supreme Court has emphasized the importance of restitution to direct victims of unfair practices in UCL actions before allowing use of fluid recovery. ${ }^{171}$ This Casenote does not question the high court's view that a court must make reasonable efforts to locate and reimburse every victim of the unfair practice before employing fluid recovery. ${ }^{172}$ At least two justiflcations support this approach. First, the UCL explicitly directs restitution to "person[s] in interest," "73 understood broadly to include past and likely future victims of unfair practices. Second, the potential for reimbursement through court action creates incentives for those most familiar with a given unfair business practice to file UCL actions: namely, the direct victims of such practices.

Yet, although reimbursement of direct victims is an important aspect of the UCL, it should not overshadow the UCL's traditional concern with the harm wrought by unfair practices on the public at large. Indeed, over the course of the history of the UCL, emphasis has shifted from protecting business competition to protecting consumers. ${ }^{174}$ The initial impetus underlying the UCL's enactment was harm to business competition. Although the courts recognized that unfair competition harms consumers, ${ }^{175}$ early decisions exhibited a distaste for using the original statute to enjoin business practices that did not clearly violate the law of unfair competition. ${ }^{176}$ Eventually, however, the focus of the UCL shifted to encompass consumer protection in its broadest sense. ${ }^{177}$ In fact, the California Supreme Court has stated that the UCL's main purpose is consumer protection. ${ }^{178}$

171. See supra Part IV.A.3.

172. See MAI Sys. Corp.v. UIPS, 856 F. Supp. 538, 542 (N.D. Cal. 1994) (holding that restitution under Section 17203 can be recovered only by the victims of a business practice).

173. CAL. Bus. \& Prof. Code $\$ 17203$ (West 1997 \& Supp. 2002).

174. See Howard, supra note 18 , at 708.

175. See People ex rel. Mosk v. Nat'l Research Co. of Cal., 20 Cal. Rptr. 516, 525 (Dist. Ct. App. 1962).

176. See Int'l Ass'n of Cleaning \& Dye House Workers v. Landowitz, 126 P.2d 609, 611 (Cal. 1942) ("The phrase 'unfair competition' when carried beyond its traditional scope in equitable actions, however, does not have a fixed meaning in the absence of statutory definition. Courts of equity, therefore, are loath to enjoin conduct on that ground in the absence of specific authorization therefor.").

177. See William L. Stern, Consumer/Investor Remedies: Using Bus. \& Prof. Code $\$$ 17200 II 2:16-2:32, at 213 (1996) (describing how the UCL has been amended and broadened).

178. Barquis v. Merch. Collection Ass'n, 496 P.2d 817, 829 (Cal. 1972). However, not every harm to consumers is actionable under the UCL:

[T] he determination of whether a particular business practice is unfair necessarily involves an examimation of its impact on its alleged victim, balanced against the reasons, justifications and inotives of the alleged wrongdoer. In brief, the court must weigh the utility of the defendant's conduct against the gravity of the harm to the alleged victim ....

Motors, Inc. v. Times Mirror Co., 162 Cal. Rptr. 543, 546 (Ct. App. 1980). 
Because the UCL's main purpose is protection of consumers, as opposed to protection of competitive business markets, it is reasonable to view the "consumer" protected by the statute as both the specific victimized consumer and the consuming public in general. Arguably, because any resident of California is entitled to pursue a UCL action in the name of the public good, the public itself has a right to compensation for harm done to it by unfair business practices. ${ }^{179}$ Put another way, the named plaintiff in a UCL action is merely a stand-in for the public, a switch necessary to get the litigation machine moving; ${ }^{180}$ and if the public sues, why should the public not recover the disgorged funds?

Although compensation of direct victims is a laudable goal, the structure and application of the UCL demonstrates that protection of the public at large is important as well. Thus, fiuid recovery's use of disgorged funds to benefit the consuming public ${ }^{181}$ is consistent with the UCL's longstanding goals, especially after a court has expended appropriate effort to identify and compensate direct victims.

179. Business and Professions Code Section 17203 permits restitution to any "person in interest." Cal. Bus. \& Prof. Code $\S 17203$ (West 1997 \& Supp. 2002). However, Section 17201 states that "[als used in this chapter, the term person shall mean and include natural persons, corporations, firms, partnerships, joint stock companies, associations and other organizations of persons." Id. § 17201. A elass of consumers hurt by unfair practices is a de facto "association of persons," brought into being by the defendant's delict. In a larger sense, it is the entire consuming public that is affected by the unfair practice, and thus the public may constitute a Section 17201 "association of persons." See People v. Thomas Shelton Powers, M.D., Inc., 3 Cal. Rptr. 2d 34, 41 (Ct. App. 1992) (stating that the term "person" as defined by Business and Professions Code Section 17201 is sufficiently broad to cover a group of natural persons, or even a city of natural persons harmed by the practice).

180. See Sharon J. Arkin, The Effective Use of California's Unfair Competition Law to Redress Managed Care Abuses, 22 WhITrIER L. Rev. 467, 497 (2001) ("The plaintiff only represents the interests of the general public. The claims of the individuals are not adjudicated, and the individuals retain whatever rights they have to bring their own individual actions."). See also Jack B. Weinstein, Compensation for Mass Private Delicts: Evolving Roles of Administrative, Criminal, and Tort Law, 2001 U. ILL. L. REv. 947, 979 (2001) (footnote omitted) (arguing that fluid recovery allows private litigants "to accomplish soine of the things the government should be doing through executive, legislative, adıninistrative, or criminal action").

181. Adnittedly, fluid recovery often only benefits a subset of consumers rather than the public at large. If Apple Computers, for example, were ordered to rollback the prices on i-Macs until ill-gotten gains were disgorged, it would be primarily the loosely defined class of counputer purchasers that benefits and not the mythical "public as a whole." Accord Market St. Ry. Co. v. R.R. Comm'n, 171 P.2d 875, 881 (Cal. 1946) (noting that the rollback of the prices on trolley tickets benefits only the trolley-using public). Similarly, establishing a consumer trust fund to address the concerns of poor tenants in San Francisco, for example, would benefit only the class of people affected by predatory renting policies, rather than the general public. However, these specific market segments satisfy the definition of a person in Section 17201, and consequently recovery to these segments is allowed under Section 17203's "person in interest" rule. But cf. Coffee, Entrepreneurial Litigation, supra note 18, at 919 n.106 ("In principle, fluid recovery is only damage averaging carried to its logical extreme, such that all potential victins (and others) receive the same financial benefit regardless of their actual injury."). 


\section{b. Fluid Recovery Is Consistent with the Modern Trend of Pragmatism in Mass Litigation}

It is somewhat myopic to discuss fluid recovery under the UCL without acknowledging the larger issues of equity inherent in the procedure. Although channeling disgorged funds away from the victims of such practices may seem unjust, ${ }^{182}$ doing so is consistent with the modern trend of praginatism in mass litigation. ${ }^{183} 1 \mathrm{t}$ is a legal fiction that the procedures of mass litigation ensure a fair adjudication of every individual claim. ${ }^{184}$ Considerations of efficiency lead courts to treat the interests of the class as unifled and stable instead of providing every plaintiff with "his day in court."185 Fluid recovery merely extends this concept to the remedy stage. As Professors Robinson and Abraham assert, "Tort law should sacrifice a measure of corrective justice-conceived as full individualization- $\mathrm{m}$ order to achieve more efficient forms of adjudication and more even-handed distribution of compensation."186 Professor Bone concurs: "individual participation values are not particularly compelling in [fluid recovery cases] because absentees have little, if any, imterest in litigating their small claims separately."187

Admittedly, depriving some plaimtiffs of direct compensation is problematic. In a perfect world, a justice system would compensate every direct victim, and the administrative costs of restitutionary procedures would be negligible. Yet, given the expense and, ultimately, wastefulness of individual restitution in mass consumer protection actions, fluid recovery is a praginatic tool to ensure disgorgement and deterrence. The interests of

182. See, e.g., Stephen Meili, A Voice Crying Out in the Wilderness: The Client in Clinical Education, 2000 WIs. L. REv. 617, 624 (2000) (observing that "the downside to the pre-distribution $c y$ pres model is that it literally takes money away from class members who are otherwise entitled to it[]]" but still endorsing fluid recovery in some cases).

183. See generally JACK B. Weinstein, Individual Justice in Mass Tort Litigation (1995).

184. It is not even clear that procedures of mass litigation should do so. See Glen O. Robinson \& Kenneth S. Abraham, Collective Justice in Tort Law, 78 VA. L. REv. 1481, 1511 (1992) ("On full reflection, the idea of defining justice in terms of unconstrained mdividualism is both quixotic and ethically dubious."); Leon E. Trakman, David Meets Goliath: Consumers Unite Against Big Business, 25 Seton Hall L. Rev. 617, 664 (1994) ("Our legal system highly values individual interests and prerogatives. But just as individualism run riot can be damaging in social inatters, so too may it need checking in mass litigations.") (citation omitted).

185. See Robinson \& Abraham, supra note 184, at 1482-83. A congruent conceptual approach to this nnodel views the class as a concrete entity. See David L. Shapiro, Class Actions: The Class as Party and Client, 73 Notre Dame L. Rev. 913, 917 (1998) (contending that "the class as entity should prevail over more individually oriented notions of aggregate litigation"). Inherently, this approach subordinates the voices of individual class members to the attorney's preferences. See Coffee, Class Action Accountability, supra note 18, at $379-80$ (noting that treating a class as an entity is similar to representing a corporation as opposed to individual shareholders, and arguing for client autonouny in class actions).

186. Robinson \& Abraham, supra note 184, at I508.

187. Robert G. Bone, Statistical Adjudication: Rights, Justice, and Utility in a World of Process Scarcity, 46 VAND. L. REv. 561, 573 (1993) (footnote omitted). 
direct victims in these cases will not be subordinated to the opaque "public good," but will bear on the trial court's decision in ordering fluid recovery. ${ }^{188}$ Furthermore, in cases of small individual claims, a cy pres distribution of the fund to beneflt the plaintiff class as a whole will achieve greater individual gains than a laborious claim procedure. Consumer trust funds, and in some cases price rollbacks, provide concrete beneflts to uncompensated class members in lieu of small cash rewards. ${ }^{189}$ Finally, fluid recovery, although an imperfect remedy, is well suited for the goals of the UCL. Because fluid recovery ensures complete disgorgement, it has a greater deterrent force than restitution. ${ }^{190}$ Given that the UCL's primary goal traditionally has been deterrence, rather than compensation, ${ }^{191}$ fluid recovery is especially appropriate in UCL cases. ${ }^{192}$

Within the UCL's framework, fluid recovery seems a natural solution for many situations involving disgorgement. Issues of conservative statutory interpretation and victim restitution are important, but rigid application of these concepts to UCL litigation is at odds with the statute's ambitious intent as well as modern trends in mass litigation. The UCL's intentionally broad provisions, its emphatic rejection of class action-type requirements, and its focus on the welfare of the public require a broad approach to consumer protection. This broad approach includes allowing courts to fashion equitable remedies, such as fluid recovery, which beneflt the public as a whole when individual victims cannot be reimbursed.

188. Any proposed balancing test features plaintiffs' interest as a factor. See infra Part IV.B.2.

189. See Geoffrey P. Miller \& Lori S. Singer, Nonpecuniary Class Action Settlements, 60 LAw \& ConTEMP. ProB. 97 (1997). See also DeJarlais, supra note 4, at 741-48 (refuting arguments that fluid recovery leads to third-party windfall, double recovery, due process problems, and the overextension of courts' equitable powers).

190. See Stephen Berry, Ending Substance's Indenture to Procedure: The Imperative for Comprehensive Revision of the Class Damage Action, 80 Colum. L. REv. 299, 299-300 (I980) (observing that small-claimant class actions promote deterrence rather than compensation goals). See also Gammon v. GC Servs. Ltd. P'ship, I62 F.R.D. 313, 32I (N.D. Ill. I995) (holding that in an action with small individual claims, disgorgement into a fluid recovery fund fulfills the deterrence objectives of class actions). For a discussion of the vagueness of Kraus on the subject of what is to be done with funds that cannot be distributed to class members, see supra Part IV.A.2.

191. See supra Part IV.B.1.(a).

192. STERN, supra note 177, at 213; see also Simer v. Rios, 661 F.2d 655 (7th Cir. 1981), cert. denied, 456 U.S. 917 (1982) (holding that courts must consider whether ordering fluid recovery would serve "various substantive policies," with one factor being whether the underlying statute has a compensatory purpose); Nat'l Ass'n of Consumer Advocates, Standards and Guidelines for Litigating and Settling Consumer Class Actions, October 8, 1997, http://www.naca.net/standards.htm (last visited Mar. 9, 2002):

In proposing a cy pres remedy, class counsel should propose a disposition of the unclaimed portion of the award that will either (1) protect the interests of the persons imjured by the illegal conduct and thus indirectly benefit absent class members or (2) promote the purposes of the statutory prohibitions sought to be enforced in the underlying litigation. 


\section{Greater Consistency with Legislative Intent Where the Costs of Notification Exceed the Benefits}

The restitution mandate set forth in Kraus is overly dogmatic and inefficient. Kraus's restriction on the ability of judges to invoke equitable powers to fashion fair remedies in many UCL cases, especially those involving widespread consumer fraud, compounds the negative implications of its rigid restitution requirement. Judicious use of the courts' equitable powers could resolve some of the difficulties created by the tension between the disgorgement and restitution remedies under the UCL.

Professor Farmer has noted that "[c]reative [fluid recovery] distribution plans ... should be favored in cases where the benefits exceed the costs." 193 An approach that permits fluid recovery when the costs of notification exceed the benefits to unidentified victims is more reasonable and more consistent with legislative intent than the rigid notification requirement imposed by Kraus. As stated by the California Supreme Court several years prior to Kraus, "it is unlikely the Legislature, in providing courts with broad equitable powers to remedy violations under [the UCL], intended those powers be limited in an illogical, unfair and counterproductive manner." 194 In addition, the federal courts have recognized the need to balance beneflts with costs by permitting fluid recovery in mass suits where individual notice is impractical. ${ }^{195}$ The California Legislature can overturn Kraus by amending the UCL to permit fluid recovery when the beneflts of notification exceed the costs, and thereby

193. Farmer, supra note 138, at 403.

194. ABC Int'1 Traders, Inc. v. Matsushita Elec. Corp., 931 P.2d 290, 304 (Cal, 1997).

195. See, e.g., Colson v. Hilton Hotels Corp., 59 F.R.D. 324 (N.D. 1ll. 1972) (hotel chain agrees to lower room rates for a defined period because it was not feasible to identify price fixing victims); State v. Chas. Pfizer \& Co., Inc., 314 F. Supp. 710 (S.D.N.Y. 1970), aff'd, 440 F.2d 1079 (2d Cir. 1971), cert. denied, 404 U.S. 871 (1971) (approving a $\$ 100$ million fluid recovery settleinent of class actions). There are also numerous federal cases where courts found fluid recovery to be appropriate after some initial disbursement to identifiable plaintiffs. See, e.g., Democratic Cent. Comm. v. Washington Metro. Area Transit Comm'n, 84 F.3d 451, 458 (D.C. Cir. 1996) (approving cy pres distributions of residue remaining after distribution to class members); In re Agent Orange Prod. Liab. Litig., 818 F.2d 179, 183-85 (2d Cir. 1987) (approving the use of a portion of the settlement fund to provide programs for the class as a whole); Nelson v. Greater Gadsden Hous. Auth., 802 F.2d 405, 409 (11th Cir. 1986) (allowing the use of fluid recovery systein); Powell v. Ga.-Pac. Corp., 843 F. Supp. 491, 499 (W.D. Ark. 1994) (permitting the use of funds to establish a scholarship fund); Superior Beverage Co., Inc. v. Oweus-11l., Inc., 827 F. Supp. 477, 479 (N.D. 1ll. 1993) (permitting use of funds for public interest purposes); Pray v. Lockheed Aircraft Corp., 644 F. Supp. 1289, 1303 (D.D.C. 1986) (distributing funds to charitable organizatious). But see Six Mexican Workers v. Ariz. Citrus Growers, 904 F.2d 1301, 1308 (9th Cir. 1990) (approving generally of cy pres but rejecting the district court's plan as not adequately aiding absent class inembers); In re Folding Carton Antitrust Litig., 744 F.2d 1252, 1254 (7th Cir. 1984) (ordering, on appeal, that the $\$ 6$ million fund escheated to the federal government inust be held for claimants, but not disapproving of cy pres distributions in appropriate cases); In re Matzo Food Prods. Litig., 156 F.R.D. 600, 605 (D.N.J. 1994) (rejecting a proposal that entire settlement fund be distributed to charities). 
make distribution of funds more efficient, equitable, and consistent with the statute's current framework.

Courts and scholars have fashioned several tests that balance these goals to arrive at a determination of when it is proper to use fluid recovery. For example, in Levi Strauss, the California Supreme Court endorsed a balancing test that would consider the amount of compensation provided to direct victims, the proportion of class members sharing in the recovery, the size and effect of the spillover to nonclass members, and the costs of administration. ${ }^{196}$ A federal court in Simer v. Rios proposed as a test considering whether fluid recovery would promote the violated statute's policies of deterrence, disgorgement, and compensation. ${ }^{197}$ In addition, Professor Farmer has suggested that the proper factors ought to be:

(1) [W] hether the class of consumers is large and difficult to identify because, for example, neither consumers nor producers maintain records of purchasers; (2) whether the product is relatively inexpensive and frequently purchased; (3) whether a creative alternative is viable to return value directly to consumers without promoting fraudulent claims or benefiting the defendant; and (4) whether the costs of any effort at direct restitution exceed the likely benefit. ${ }^{198}$

Although Professor Farmer's test seems to fit the unique problems posed by consumer protection suits under the UCL particularly well, each of these tests reflect concerns with efficiency, fairness to the direct victims, and deterrence. Indeed, employment of any one of these tests is a better fit for the complexities of mass litigation than Kraus's rigid and inefficient restitution requirement.

\section{Improved Quality of Consumer Protection Through Grants to Consumer Groups}

If fluid recovery is available under the UCL, grants to consumer advocacy organizations will benefit the consumer groups victimized by unfair practices and will reduce abuses of the UCL in litigation. First, targeted grants promise to improve the condition of consumers affected by an unfair business practice and those who were potential victims of the unfair practice. For example, im Vasquez, the court ordered the UCL defendant to pay $\$ 1.4$ million to a consumer group. ${ }^{199}$ Under the general supervision of the plaintiff's counsel and the ultimate oversight of the trial court, the consumer group "monitored consumer credit problems of low and moderate income consumers in California, sponsored and opposed legislation on the

196. State v. Levi Strauss \& Co., 715 P.2d 564, 576 (Cal. 1986).

197. 661 F.2d 655, 676 (7th Cir. 1981), cert. denied, 456 U.S. 917 (1982).

198. Farmer, supra note 138, at 405 (footnote omitted). See also Miller \& Singer, supra note 189.

199. See supra Part IV.A.2. 
state level involving low and moderate income consumer credit issues, and litigated cases involving issues of concern to low and moderate income consumers in California." ${ }^{200}$ Similarly, in People v. ITT Consumer Financial Corp., the terms of the stipulated judgment required the defendant to refund its customers and pay $\$ 10$ million to create a pernanent endowment for a consumer protection trust fund. ${ }^{201}$ That money supported investigations, prosecutions, and enforcement of consumer protection actions. ${ }^{202}$ Commenting on this outcome, Professor McCall has noted that "[p]ersons who suffered from the practices alleged in the suit, who do not benefit from direct restitution, may nonetheless benefit indirectly by the increased consumer protection law enforcement efforts that will be funded."203

These examples suggest consumer trust funds are an appealing and efficient alternative to the wild-goose chase of reimbursing direct victims who cannot be located or who receive the claim envelope but who do not understand its significance. Furthermore, although the consumer trust funds in Vasquez and ITT had broad missions, courts may more narrowly tailor other fiuid recovery plans. For example, a court could grant funds froin a case of false advertisement to a truth-in-advertising group. Similarly, in a case of unlawful or unfair business practices by a car-rental company, ${ }^{204}$ bank, ${ }^{205}$ or insurance company, ${ }^{206}$ a court could focus grants such that they reach consumers in the particular industry involved in the lawsuit. By carefully tailoring the award of fluid recovery funds to a consumer group, courts may avoid benefiting classes of customers that were either unaffected or unlikely to be affected by the unfair business practice. ${ }^{207}$

The second benefit of channeling funds recovered in UCL actions to consumer protection groups is that it will reduce the number of suits brought by plaintiffs' lawyers, thus reducing abuses of the statute, assuming a finite number of businesses employ unlawful or unfair tactics at any one time. ${ }^{208}$

\footnotetext{
200. McCall, supra note 29 , at $848-49$.

201. Id. at 844-45.

202. Id. at 845 .

203. Id.

204. See People v. Dollar Rent-A-Car Sys., Inc., 259 Cal. Rptr. 191 (Ct. App. 1989).

205. See In re Morpheus Lights, Inc., 228 B.R. 449 (N.D. Cal. 1998).

206. See Wilner v Sunset Life Ins. Co., 93 Cal. Rptr. 2d 413 (Ct. App. 2000).
}

207. In other words, a person who has not ever and does not ever plan to rent a car will not be affected by the industry-specific activities of a consumer protection group. Only the existing victims or likely potential victims are benefited.

208. Arguably, this suggestion contradicts the spirit of the UCL which specifically authorized private citizens to bring UCL suits. CAL. Bus. \& PROF. CODE. $\$ 17204$ (West 1997 \& Supp. 2002). However, the statute does not indicate that certain types of plaintiffs are more desirable than others. Rather, it permits a victim, a third party, a district attorney, or an organization to function as plaintiff. As long as UCL suits are prosecuted successfully, unfair business practices will be deterred and the goals of the statute will be served regardless of the namie on the pleading. 
Admittedly, increased funding for consumer groups may increase the volume of UCL litigation in California. Litigation in the true interest of the public, however, is an innate benefit. For instance, the shift in UCL representation from private plaintiffs' lawyers to non-profit consumer protection groups may improve the quality of consumer protection in California. Because such consumer groups are non-profit, they are more likely to litigate cases involving egregious practices, even though they may be difficult to prove in court. Consumer groups may also be more amenable to pursuing cases to clarify legal precedent. In contrast, profit motive and resource constraints limit private plaintiffs' attorneys, and therefore they may be more willing to settle cases early or decline cases altogether. Thus, channeling litigation away from private attorneys may improve the UCL's image in the eyes of legislators and the public.

\section{CONCLUSION}

California's Unfair Competition Law is a potent weapon for the state's consumers. At the same time, the UCL is a powerful foe for California's businesses; as interpreted by the courts, it looms as a potentially bankrupting force that threatens to entwine defendants in endless lawsuits of dubious merit. In Kraus v. Trinity Management Services, the California Supreme Court improperly prohibited disgorgement into a fluid recovery fund in UCL actions. Certainly, California must rein in the UCL and bring it in line with the narrower consumer protection laws of other states. Yet, while reforming the UCL's lack of a standing requirement and the statute's prohibition of "unfair" practices is reasonable, ${ }^{209}$ placing limits on recovery options available under the statute is not.

Kraus leads to impractical outcomes, including wasteful and burdensome restitution procedures that rigidly limit courts' equitable powers. In addition, Kraus needlessly funnels consumer protection suits into procedurally complicated and costly class action litigation. Furthermore, by emphasizing restitution over disgorgement, the decision undermines disgorgement's deterrent effects. These consequences run contrary both to the legislature's intent in adopting the UCL and to the strong tradition of consumer protection in California. Although fluid recovery is not an ideal solution because it inherently denies compensation to some direct victims, it remains the most practical way of distributing disgorged funds in cases of extensive unfair practices resulting in small individual claims. Even in cases where the individual clains are not negligible, but where direct victims cannot be located, fluid recovery is a pragmatic and equitable method of disposing of residue funds. Thoughtful and conscientious use of fluid

209. Numerous legislative attempts to do so have failed. Currently, business groups and the defense bar are leading a petition to reform the UCL through a ballot initiative. See Kevin Livingston, Taking the Initiative, THE RECORDER, Dec. 19, 2001, at 1 . 
recovery by California courts will benefit the public without making the state hostile to businesses. Accordingly, the legislature should counteract the negative consequences of Kraus by expressly amending the UCL to pernit fiuid recovery. 
